\title{
Use of Nutritional Requirements for Brettanomyces bruxellensis to Limit Infections in Wine
}

\author{
Nicolas H. von Cosmos and Charles G. Edwards * \\ School of Food Science, Washington State University, Pullman, WA 99164-6376, USA; nickhogrefe@gmail.com \\ * Correspondence: edwardsc@wsu.edu; Tel.: +1-509-335-6612
}

Academic Editor: Badal C. Saha

Received: 30 June 2016; Accepted: 29 August 2016; Published: 9 September 2016

\begin{abstract}
Specific vitamin requirements of the wine spoilage yeast, Brettanomyces bruxellensis, were evaluated. Previous studies had not taken into influences of ethanol or nutrient carry-over between sequential transfers into vitamin-omitted media. Knowing nutritional needs, limiting growth of the yeast in wine by selective removal of important vitamins was investigated. Six strains of B. bruxellensis were grown and sequentially transferred into single vitamin-omitted media. None of the strains required $p$-aminobenzoic acid, folic acid, nicotinic acid, myo-inositol, pantothenic acid, or riboflavin. While some needed thiamin depending on the absence/presence of ethanol, growth of all strains was greatly affected by biotin. Here, concentrations $\geq 0.2 \mu \mathrm{g} / \mathrm{L}$ were required to achieve yeast populations $>10^{6} \mathrm{cfu} / \mathrm{mL}$ for high $\left(10^{4} \mathrm{cfu} / \mathrm{mL}\right)$ or low $\left(10^{2} \mathrm{cfu} / \mathrm{mL}\right)$ initial inoculums. At concentrations $<0.2 \mu \mathrm{g} / \mathrm{L}$, culturabilities either remained unchanged or increased less than two logs after 40 days. Since the protein avidin binds irreversibly to biotin, egg whites containing avidin or the purified protein were added to a wine to diminish bioavailability of the vitamin. While biotin concentrations were reduced, populations of B. bruxellensis achieved were decreased by one to three logs, thereby supporting further development of biotin depletion strategies in winemaking.
\end{abstract}

Keywords: brettanomyces; nutrition; vitamins; biotin; avidin; wine

\section{Introduction}

The spoilage yeast Brettanomyces bruxellensis is generally regarded as detrimental to wine production [1]. Unfavorable sensory descriptors of "leather", "clove", "spice", "smoke", "animal", "stable", "earth", "cardboard", and "medicinal" are among those used to describe the characteristics of wine spoiled by this yeast [2-4].

Although low amounts of sugar $(<0.275 \mathrm{~g} / \mathrm{L})$ or yeast assimilable nitrogen $(<6 \mathrm{mg} \cdot \mathrm{N} / \mathrm{L})$ remaining after primary fermentation are sufficient for spoilage during red wine aging [5-7], little is known regarding its requirements for trace nutrients (e.g., vitamins and minerals). Pyridoxine, thiamine, and/or biotin are thought to be required by B. bruxellensis, as evidenced by deterred growth in vitamin-omitted media [8-10]. However, previous studies did not account for the effects of vitamin carry-over between media transfers [11], genetic heterogeneity between strains [8,12], or the presence of ethanol in the test media as would be present in wine $[13,14]$.

B. bruxellensis can grow over a wide range of $\mathrm{pH}$, temperatures, oxygen availability, sulfites, and ethanol levels [13-17]. As such, winemakers frequently rely upon multiple strategies to limit microbial spoilage [18]. Individual strategies have included the applications of sulfites [15,16,19], filtration [20], extreme temperatures [8,15,17,21], ethanol [13,14], ozone [22], pulsed electric field [23], low electric current [24], chitosan [25], dimethyl dicarbonate [26,27], and others. In fact, combinations of these strategies can help limit infections through synergistic interactions and variable tolerances by strains [28,29]. 
In addition to these individual strategies, another potential method to reduce spoilage could be removal of required nutrients. For example, if a given vitamin were uniformly required by B. bruxellensis, reducing its bioavailability in wines may help limit infections. Thus, the objectives of this study were to (a) determine specific vitamin requirements of B. bruxellensis while accounting for vitamin carry-over and presence of ethanol, and (b) evaluate strategies to selectively remove specific vitamin(s) from wine. In general, all strains studied required biotin whose removal from wine resulted in limiting growth over an incubation period of 40 days.

\section{Materials and Methods}

\subsection{Strains}

B. bruxellensis strains B1b, E1, I1A and N2 were originally described by Jensen et al. [16] (Washington State University, Pullman, WA, USA). Strains 2049 and 2091, isolated from New Zealand and French wines, respectively, were obtained from the Phaff Yeast Culture Collection (University of California, Davis, CA, USA). All strains were stored in $30 \% w / w$ glycerol at $-80{ }^{\circ} \mathrm{C}$, maintained on WL agar (Fisher Scientific, Waltham, MA, USA), and grown at $25^{\circ} \mathrm{C}$.

\subsection{Nutritional Requirements}

Vitamin needs were assessed in a growth medium described by Kurtzman et al. [30] with all reagents and vitamins obtained from Sigma-Aldrich (St. Louis, MO, USA). Briefly, the base medium consisted of glucose $(10 \mathrm{~g} / \mathrm{L}),\left(\mathrm{NH}_{4}\right)_{2} \mathrm{SO}_{4}(5 \mathrm{~g} / \mathrm{L}), \mathrm{KH}_{2} \mathrm{PO}_{4}(0.85 \mathrm{~g} / \mathrm{L}), \mathrm{MgSO}_{4}(0.5 \mathrm{~g} / \mathrm{L}), \mathrm{K}_{2} \mathrm{HPO}_{4}$ $(0.15 \mathrm{~g} / \mathrm{L}), \mathrm{NaCl}(0.1 \mathrm{~g} / \mathrm{L}), \mathrm{CaCl}_{2}(0.1 \mathrm{~g} / \mathrm{L})$, DL-methionine $(20 \mathrm{mg} / \mathrm{L})$, DL-tryptophan $(20 \mathrm{mg} / \mathrm{L})$, L-histidine monohydrochloride $(10 \mathrm{mg} / \mathrm{L}), \mathrm{H}_{3} \mathrm{BO}_{3}(500 \mu \mathrm{g} / \mathrm{L}), \mathrm{MnSO}_{4}(400 \mu \mathrm{g} / \mathrm{L}), \mathrm{ZnSO}_{4}(400 \mu \mathrm{g} / \mathrm{L})$, $\mathrm{FeCl}_{3}(200 \mu \mathrm{g} / \mathrm{L}), \mathrm{Na}_{2} \mathrm{MoO}_{4}(200 \mu \mathrm{g} / \mathrm{L}), \mathrm{KI}(100 \mu \mathrm{g} / \mathrm{L})$, and $\mathrm{CuSO}_{4}(40 \mu \mathrm{g} / \mathrm{L})$ and was adjusted to pH 3.5 with $\mathrm{HCl}$. The vitamins examined were $p$-aminobenzoic acid $(200 \mu \mathrm{g} / \mathrm{L})$, biotin $(2 \mu \mathrm{g} / \mathrm{L})$, folic acid $(2 \mu \mathrm{g} / \mathrm{L})$, myo-inositol $(2 \mathrm{mg} / \mathrm{L})$, nicotinic acid $(400 \mu \mathrm{g} / \mathrm{L})$, calcium pantothenate $(400 \mu \mathrm{g} / \mathrm{L})$, pyridoxine hydrochloride $(400 \mu \mathrm{g} / \mathrm{L})$, riboflavin $(200 \mu \mathrm{g} / \mathrm{L})$, and thiamin $(1 \mathrm{mg} / \mathrm{L})$ at concentrations recommended by Kurtzmann et al. [30]. Vitamins were individually sterile-filtered through $0.22 \mu \mathrm{m}$ filters and aseptically added to previously autoclaved media (15 min at $\left.121^{\circ} \mathrm{C}\right)$. All solutions and media were wrapped in aluminum foil to prevent potential light degradation and glassware was rinsed in $1 \mathrm{~N} \mathrm{HCl}$ after washing to remove any trace residual material.

Media were transferred into $15 \times 150 \mathrm{~mm}$ Klett tubes $(4.2 \mathrm{~mL})$, fitted with Identi-Plug foam inserts (Jaece Industries, North Tonawanda, NY, USA) and plastic dilution blank caps, and autoclaved. Once cooled, vitamin solutions and a mixture of distilled water/ethanol were aseptically added to yield $5 \mathrm{~mL}$ total volume containing $0 \%$ or $10 \% v / v$ ethanol. Strains of B. bruxellensis were inoculated into triplicate tubes at $10^{4} \mathrm{cfu} / \mathrm{mL}$. Turbidity was assessed using a Klett-Summerson photoelectric colorimeter equipped with a green filter (Klett Manufacturing Co., New York, NY, USA). Upon reaching a turbidity of 75 Klett units (or as close as possible), cultures were centrifuged at $3000 \times g$ for $20 \mathrm{~min}$ and pellets washed $3 \times$ with $10 \mathrm{~mL} 0.2 \mathrm{M}$ phosphate buffer ( $\mathrm{pH} 7.0$ ) made up of $9.36 \mathrm{~g} / \mathrm{L}$ potassium phosphate monobasic, anhydrous and $32.73 \mathrm{~g} / \mathrm{L}$ sodium phosphate dibasic heptahydrate (Fisher Scientific). After the final wash, cells were resuspended in $5 \mathrm{~mL} 0.2 \mathrm{M}$ phosphate buffer and re-inoculated ( $1 \% \mathrm{v} / \mathrm{v})$ into $15 \mathrm{~mm} \times 150 \mathrm{~mm}$ Klett tubes containing $5 \mathrm{~mL}$ fresh media. Harvesting cells and reinoculation into vitamin-omitted media was repeated to yield three sequential transfers $\left(\mathrm{S}_{1} \rightarrow \mathrm{S}_{2} \rightarrow \mathrm{S}_{3}\right)$.

Using the medium described above, the influence of concentrations of biotin on B. bruxellensis growth was evaluated. Culturable populations were determined by Autoplate ${ }^{\circledR} 4000$ spiral plater (Spiral Biotech, Bethesda, MD, USA) using WL agar spread plates. Starter cultures were prepared by harvesting cells and sequential reinoculation (twice) into biotin-omitted media. 


\subsection{Biotin Removal}

Residual sulfites present in a commercial red wine (2014 Carlo Rossi Burgundy, Modesto, CA, USA) were removed by addition of $3 \% v / v \mathrm{H}_{2} \mathrm{O}_{2}$ as confirmed by measurement of total $\mathrm{SO}_{2} \mathrm{using}$ the aeration-oxidation method [31]. Glucose $(0.5 \mathrm{~g} / \mathrm{L})$, fructose $(0.5 \mathrm{~g} / \mathrm{L})$, yeast extract $(0.1 \mathrm{~g} / \mathrm{L})$, and $p$-coumaric acid $(20 \mathrm{mg} / \mathrm{L})$ were added to the wine prior to filtration through $0.45 \mu \mathrm{m}$ (Fisher Scientific). Based on the initial concentration of biotin in the wine as determined by the microbiological method described by Angyal [32], additional vitamin was added to yield a total concentration of $2 \mu \mathrm{g} / \mathrm{L}$. The wine was distributed into $1 \mathrm{~L}$ sterilized bottles before addition of either purified avidin (Fisher Scientific) or egg whites, which contain avidin and are used as fining agents in the wine industry. Avidin powder (0.2 g) was added to dialysis tubing (MWCO = $1000 \mathrm{kDa}$, Fisher Scientific) and continually mixed on a stir plate for $24 \mathrm{~h}$. Egg whites $(27 \mathrm{~g})$ were mixed with $40 \mathrm{~mL}$ distilled $\mathrm{H}_{2} \mathrm{O}$ and $0.85 \mathrm{~g} \mathrm{KCl}$ with $8 \mathrm{~mL}$ of this suspension was added to the wine which was continually mixed for 14 days. Wine aliquots were removed at various time points and immediately frozen $\left(-80{ }^{\circ} \mathrm{C}\right)$ for biotin quantification. Remaining wines were filtered through $0.45 \mu \mathrm{m}$, divided into triplicate $500 \mathrm{~mL}$ bottles (330 mL each), and inoculated with biotin-omitted starter cultures of B. bruxellensis strains 2091 or I1a at initial populations of $10^{4}$ or $10^{2} \mathrm{cfu} / \mathrm{mL}$.

\subsection{Statistics}

Differences in average maximum populations $\left(\mathrm{x}_{\max }\right)$ calculated as log values were evaluated using ANOVA and Tukey's HSD by XLSTAT (Addinsoft, New York, NY, USA). Figure data points were presented as mean \pm standard deviation (vertical bars).

\section{Results}

Strains of B. bruxellensis were inoculated into synthetic media lacking one of nine vitamins and without/with addition of $10 \% v / v$ ethanol. Neither strain E1 or I1a required $p$-aminobenzoic acid, folic acid, nicotinic acid, pantothenic acid, pyridoxine, riboflavin, nor thiamin, as evidenced by strong growth after three transfers into vitamin-omitted media (Table 1 ). With $10 \%$ ethanol added, both strains exhibited delayed growth in the absence of myo-inositol or thiamin, an effect not observed in media without ethanol. However, growth of strains E1 and I1a was delayed and then limited (<75 Klett) by the third transfer in media without biotin regardless of ethanol content.

Table 1. Growth of Brettanomyces bruxellensis strains E1 and I1a after sequential transfers in defined synthetic wine medium.

\begin{tabular}{|c|c|c|c|c|c|c|c|c|c|c|c|c|}
\hline \multirow{4}{*}{ Omitted Vitamin } & \multicolumn{12}{|c|}{ Strain } \\
\hline & \multicolumn{6}{|c|}{ E1 } & \multicolumn{6}{|c|}{ I1a } \\
\hline & \multicolumn{3}{|c|}{ 0\% Ethanol } & \multicolumn{3}{|c|}{$10 \%$ Ethanol } & \multicolumn{3}{|c|}{$0 \%$ Ethanol } & \multicolumn{3}{|c|}{$10 \%$ Ethanol } \\
\hline & $\mathrm{S}_{1} *$ & $\mathrm{~S}_{2}$ & $\mathrm{~S}_{3}$ & $S_{1}$ & $\mathrm{~S}_{2}$ & $\mathrm{~S}_{3}$ & $\mathrm{~S}_{1}$ & $\mathrm{~S}_{2}$ & $\mathrm{~S}_{3}$ & $\mathrm{~S}_{1}$ & $\mathrm{~S}_{2}$ & $\mathrm{~S}_{3}$ \\
\hline None (Control) & ++ & ++ & ++ & ++ & ++ & ++ & ++ & ++ & ++ & ++ & ++ & ++ \\
\hline$p$-Aminobenzoic acid & ++ & ++ & ++ & ++ & ++ & ++ & ++ & ++ & ++ & ++ & ++ & ++ \\
\hline Biotin & $++^{d}$ & + & - & $++\mathrm{d}$ & $++\mathrm{d}$ & + & $++\mathrm{d}$ & + & - & $++\mathrm{d}$ & $++\mathrm{d}$ & + \\
\hline Folic acid & ++ & ++ & ++ & ++ & ++ & ++ & ++ & ++ & ++ & ++ & ++ & ++ \\
\hline myo-Inositol & ++ & ++ & ++ & $++d$ & $++^{d}$ & $++{ }^{d}$ & ++ & ++ & ++ & ++ & $++d$ & $++{ }^{d}$ \\
\hline Nicotinic acid & ++ & ++ & ++ & ++ & ++ & ++ & ++ & ++ & ++ & ++ & ++ & ++ \\
\hline Pantothenic acid & ++ & ++ & ++ & ++ & ++ & ++ & ++ & ++ & ++ & ++ & ++ & ++ \\
\hline Pyridoxine & ++ & ++ & ++ & ++ & ++ & ++ & ++ & ++ & ++ & ++ & ++ & ++ \\
\hline Riboflavin & ++ & ++ & ++ & ++ & ++ & ++ & ++ & ++ & ++ & ++ & ++ & ++ \\
\hline Thiamin & ++ & ++ & ++ & $++\mathrm{d}$ & $++d$ & $++\mathrm{d}$ & ++ & ++ & ++ & $++\mathrm{d}$ & $++\mathrm{d}$ & $++d$ \\
\hline
\end{tabular}

* Relative turbidity in first $\left(\mathrm{S}_{1}\right)$, second $\left(\mathrm{S}_{2}\right)$, or third $\left(\mathrm{S}_{3}\right)$ culture transfers defined as $++(>75 \mathrm{Klett}) ;+(10-74 \mathrm{Klett})$;

or $-(<10 \mathrm{Klett}) ;{ }^{\mathrm{d}}$ Growth reached 75 Klett but was delayed by more than $24 \mathrm{~h}$ compared to the control.

Requirements for biotin, myo-inositol or thiamin were further studied using additional yeast strains (Table 2). Similar to E1 and I1a, strains B1b, N2, 2049, and 2091 exhibited only limited growth 
by the third transfer in the absence of biotin regardless of ethanol content. Without myo- inositol, none of the strains were affected in media lacking ethanol, while B1b and N2 exhibited delayed growth with $10 \%$ ethanol. Exclusion of thiamin produced a range of responses, with no growth by B1b (without ethanol) or 2091 (with ethanol) and delayed growth by N2 or 2049 by the third transfer.

Table 2. Growth of Brettanomyces bruxellensis strains B1b, N2, 2049, and 2091 after sequential transfers in defined synthetic wine medium.

\begin{tabular}{|c|c|c|c|c|c|c|c|c|c|c|c|c|c|}
\hline \multirow{3}{*}{$\begin{array}{l}\text { Ethanol } \\
(\% v / v)\end{array}$} & \multirow{3}{*}{ Omitted Vitamin } & \multicolumn{12}{|c|}{ Strain } \\
\hline & & \multicolumn{3}{|c|}{ B1b } & \multicolumn{3}{|c|}{ N2 } & \multicolumn{3}{|c|}{2049} & \multicolumn{3}{|c|}{2091} \\
\hline & & $\mathrm{S}_{1} *$ & $\mathrm{~S}_{2}$ & $\mathrm{~S}_{3}$ & $\mathrm{~S}_{1}$ & $\mathrm{~S}_{2}$ & $\mathrm{~S}_{3}$ & $\mathrm{~S}_{1}$ & $\mathrm{~S}_{2}$ & $\mathrm{~S}_{3}$ & $\mathrm{~S}_{1}$ & $\mathrm{~S}_{2}$ & $\mathrm{~S}_{3}$ \\
\hline \multirow{4}{*}{$0 \%$} & None (Control) & ++ & ++ & ++ & ++ & ++ & ++ & ++ & ++ & ++ & ++ & ++ & ++ \\
\hline & Biotin & ++ & $++d$ & + & $++d$ & $++d$ & + & $++d$ & $++d$ & + & $++d$ & $++d$ & + \\
\hline & myo-Inositol & ++ & ++ & ++ & ++ & ++ & ++ & ++ & ++ & ++ & ++ & ++ & ++ \\
\hline & Thiamin & ++ & + & - & $++d$ & ++ & ++ & $++d$ & ++ & ++ & ++ & ++ & ++ \\
\hline \multirow{4}{*}{$10 \%$} & None (Control) & ++ & ++ & ++ & ++ & ++ & ++ & ++ & ++ & ++ & ++ & ++ & ++ \\
\hline & Biotin & ++ & $++{ }^{d}$ & + & $++{ }^{d}$ & $++d$ & + & ++ & $++d$ & + & ++ & $++d$ & - \\
\hline & myo-Inositol & $++\mathrm{d}$ & $++d$ & $++d$ & ++ & $++d$ & $++d$ & ++ & ++ & ++ & ++ & ++ & ++ \\
\hline & Thiamin & $++{ }^{d}$ & $++d$ & $++d$ & $++d$ & $++\mathrm{d}$ & $++d$ & ++ & $++\mathrm{d}$ & $++d$ & ++ & + & - \\
\hline
\end{tabular}

${ }^{*}$ Relative turbidity in first $\left(\mathrm{S}_{1}\right)$, second $\left(\mathrm{S}_{2}\right)$, or third $\left(\mathrm{S}_{3}\right)$ culture transfers defined as ++ (>75 Klett); + $(10-74$ Klett);

or $-(<10 \mathrm{Klett}) ;{ }^{\mathrm{d}}$ Growth reached 75 Klett but was delayed by more than $24 \mathrm{~h}$ compared to the control.

Biotin dependence was further investigated by culturing B. bruxellensis in the presence of varying concentrations ( 0 to $2 \mu \mathrm{g} / \mathrm{L}$ ). In general, the extent of growth depended on the concentration of biotin present as well as initial populations. Here, strains 2091 (Figure 1) and I1a (Figure 2) could be recovered from biotin-omitted media where populations only increased less than one log 40 days after inoculation. When concentrations increased from 0.002 to $2 \mu \mathrm{g} / \mathrm{L}$, average maximum populations $\left(x_{\max }\right)$ also increased. With an initial inoculum of $10^{4} \mathrm{cfu} / \mathrm{mL}$, strains 2091 (Figure 1a) and I1a (Figure 2a) both reached $x_{\max }$ values of $>2.0 \times 10^{7} \mathrm{cfu} / \mathrm{mL}$ in the medium containing $2 \mu \mathrm{g} / \mathrm{L}$ biotin while peak populations were $<3.1 \times 10^{5} \mathrm{cfu} / \mathrm{mL}$ with $0.002 \mu \mathrm{g} / \mathrm{L}$. At a lower initial inoculum $\left(10^{2} \mathrm{cfu} / \mathrm{mL}\right)$, a bigger effect was noted. Here, strains 2091 (Figure 1b) and I1a (Figure 2b) reached $x_{\max }$ values of $>1.7 \times 10^{7} \mathrm{cfu} / \mathrm{mL}$ with $2 \mu \mathrm{g} / \mathrm{L}$ biotin but $<1.4 \times 10^{3} \mathrm{cfu} / \mathrm{mL}$ at the lowest concentration tested.

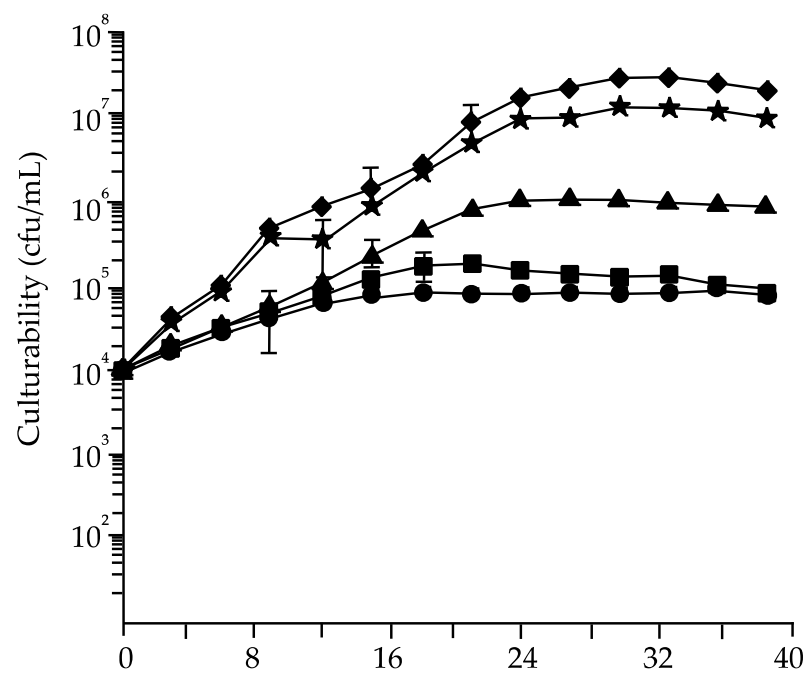

(a)

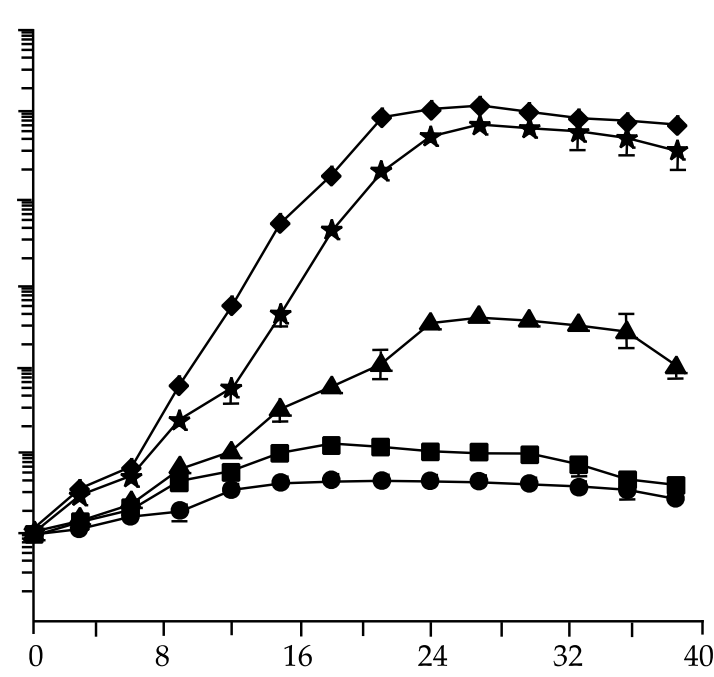

(b)

Time (days)

Figure 1. Culturabilities of Brettanomyces bruxellensis strains 2091 inoculated at (a) $10^{4}$ or (b) $10^{2} \mathrm{cfu} / \mathrm{mL}$ in media containing $0(\star), 0.002(\bullet), 0.02(\boldsymbol{\Delta}), 0.2(\boldsymbol{\square})$, or $2(\diamond) \mu \mathrm{g} / \mathrm{L}$ biotin. 


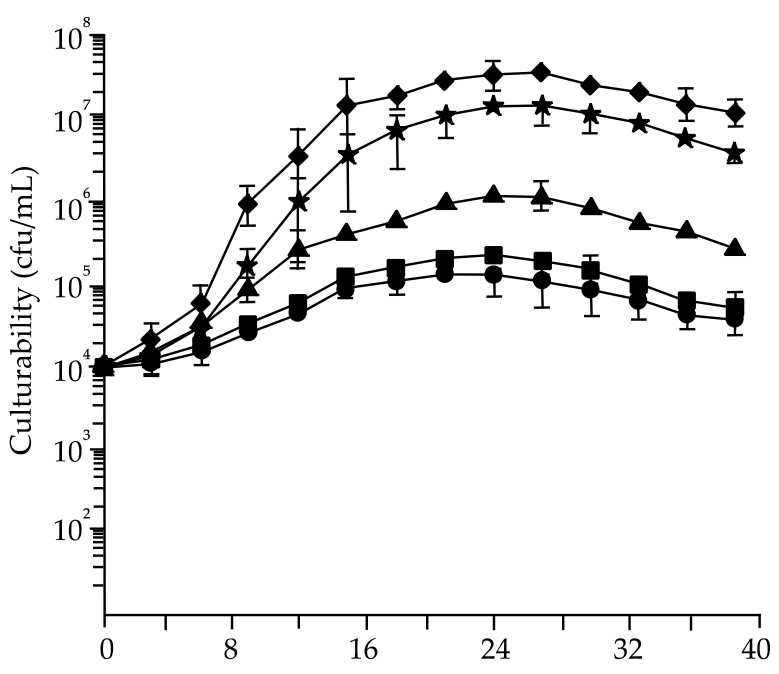

(a)

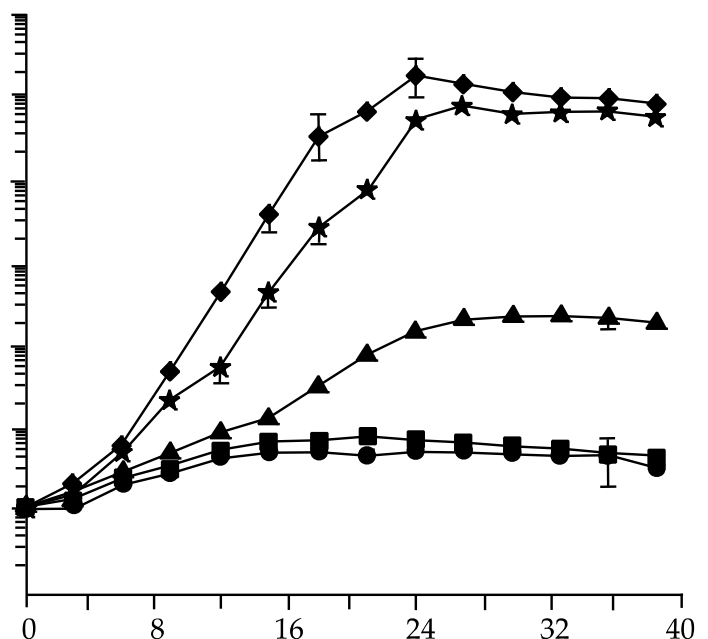

(b)

Time (days)

Figure 2. Culturabilities of Brettanomyces bruxellensis strains I1a inoculated at (a) $10^{4}$ or (b) $10^{2} \mathrm{cfu} / \mathrm{mL}$ in media containing $0(\star), 0.002(\bullet), 0.02(\boldsymbol{\Delta}), 0.2(\boldsymbol{\square})$, or $2(\diamond) \mu \mathrm{g} / \mathrm{L}$ biotin.

Based on the impact of biotin on B. bruxellensis, methods were evaluated which could make the vitamin biochemically unavailable to thereby limit growth. Here, addition of egg whites or avidin to a red wine decreased biotin concentrations from an initial concentration of $1.9 \mu \mathrm{g} / \mathrm{L}$ down to $<0.15 \mu \mathrm{g} / \mathrm{L}$ (data not shown), which resulted in decreases of $x_{\max }$ for the two strains studied. When inoculated at $10^{4} \mathrm{cfu} / \mathrm{mL}$, strains 2091 (Figure 3a) and I1a (Figure 4a) both achieved a $x_{\max }$ of $>1.5 \times 10^{7} \mathrm{cfu} / \mathrm{mL}$ in untreated wines while those with egg whites or avidin added reached lower populations. Impacts of these treatments were more pronounced at a lower initial inoculum level $\left(10^{2} \mathrm{cfu} / \mathrm{mL}\right.$ ) where populations of strains 2091 (Figure 3b) and I1a (Figure $4 \mathrm{~b}$ ) were $<4.5 \times 10^{3} \mathrm{cfu} / \mathrm{mL}$ in treated wines. In comparison, untreated wines achieved $x_{\max }$ of $>4.9 \times 10^{6} \mathrm{cfu} / \mathrm{mL}$.
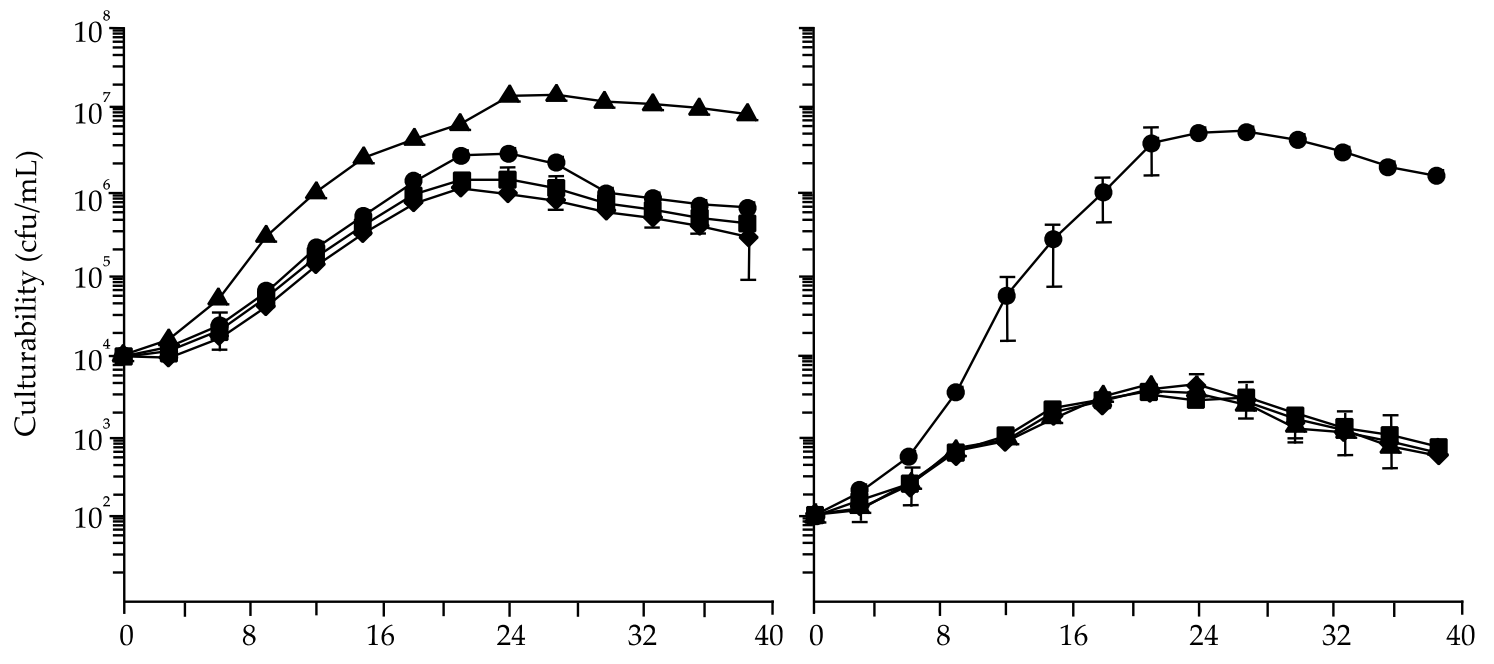

(a)

Time (days)

(b)

Figure 3. Culturabilities of Brettanomyces bruxellensis strains 2091 inoculated at (a) $10^{4}$ or (b) $10^{2} \mathrm{cfu} / \mathrm{mL}$ in wines with no additions ( $)$, with egg whites for $24(\mathbf{\Delta})$ or $336 \mathrm{~h}(\boldsymbol{\square})$, or with avidin suspended in dialysis tubing for $24 \mathrm{~h}(\bullet)$. 


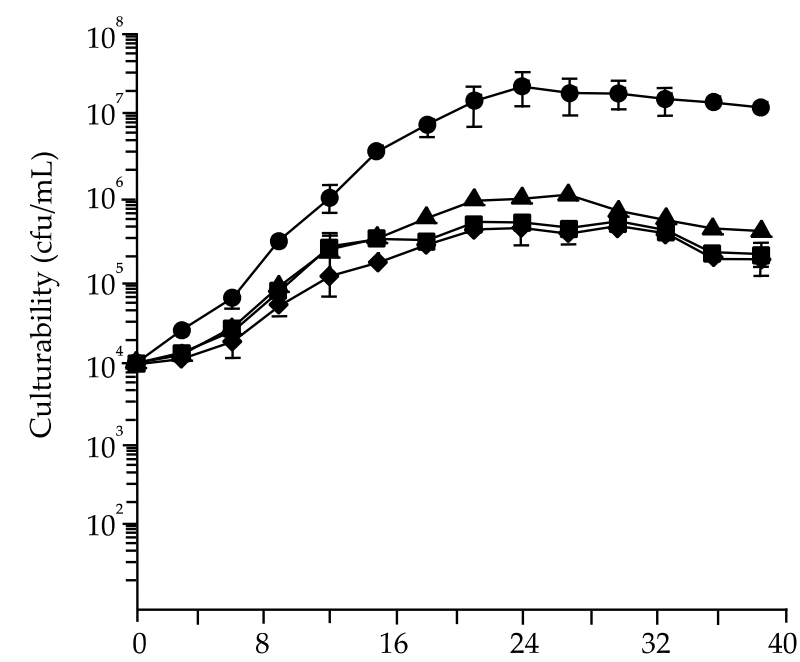

(a)

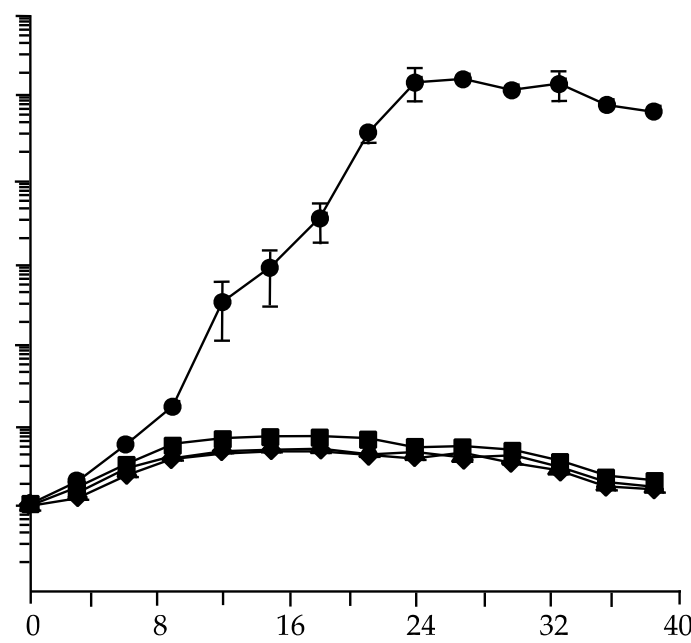

(b)

Time (days)

Figure 4. Culturabilities of Brettanomyces bruxellensis strains I1a inoculated at (a) $10^{4}$ or (b) $10^{2} \mathrm{cfu} / \mathrm{mL}$ in wines with no additions $(\boldsymbol{\vee})$, with egg whites for $24(\boldsymbol{\Delta})$ or $336 \mathrm{~h}(\boldsymbol{\square})$, or with avidin suspended in dialysis tubing for $24 \mathrm{~h}(\bullet)$.

\section{Discussion}

Initially, the vitamin requirements of two B. bruxellensis strains isolated from Washington state wines [16] were determined both with and without $10 \%$ ethanol, conditions similar to growth in wine. These strains were chosen for differences in region of isolation, antimicrobial tolerance, and genetic cluster $[8,16]$. Similar to previous work $[8,9,11]$, growth of strains E1 and I1a was unaffected by the absence of $p$-aminobenzoic acid, folic acid, nicotinic acid, myo-inositol, pantothenic acid, or riboflavin. Thiamin was also not required by the yeast without ethanol, in agreement with some $[9,33]$ but not others $[8,10]$. Similarly, pyridoxine was not found to be required, supporting some studies $[10,13,33,34]$ but contradicting others [9]. Finally, biotin was required by both strains, in agreement with previous findings $[8,10]$ but not others $[9,33]$. While additional strains studied (B1b, $\mathrm{N} 2,2049$, and 2091) all required biotin, results regarding thiamin and myo-inositol varied by strain and presence of ethanol. In fact, myo-inositol was only required by strains B1b and N2 in 10\% ethanol, possibly due to ethanol-induced increases in yeast membrane fluidity [35], which could affect vitamin transport. From a winemaking perspective, these findings imply that vitamin requirements between strains will differ depending on the stage of vinification when infection occurs, i.e., before or after alcoholic fermentation.

Vitamin carry-over and strain (genetic) diversity may have contributed to discrepancies in the literature regarding nutritional requirements of B. bruxellensis. As growth was more affected by biotin omission by the third transfer than in the first, this potentially explains why the early work of Burkholder et al. [9] did not report a requirement for this vitamin. However, Madan and Gulati [33] found none of the vitamins tested to be required despite accounting for vitamin carry-over. The present findings suggest that, with the exception of biotin, strain (genetic) diversity and presence of such components as ethanol also affects requirements. Here, strains E1, I1a, B1b and N2 were assigned to genetic cluster b while strains 2049 and 2091 were in clusters a and c, respectively [8]. Biochemically, biotin is involved in pyruvic acid carboxylation and the synthesis of pyrimidine bases, pyridine nucleotides, proteins, polysaccharides, and fatty acids. As such, deficiencies have been linked to damage of the yeast plasma membrane [36], as well as limiting maximum populations achieved in wine.

Because biotin was required by all strains examined and concentrations were correlated to growth in media, the possibility that making this vitamin unavailable to limit spoilage in a commercial wine 
was evaluated. Avidin, a protein found in egg white [37], selectively binds biotin [38] and has been applied as a means to remove biotin from chemical solutions [39,40]. With dissociation constants $\left(\mathrm{K}_{\mathrm{d}}\right)$ of $10^{-15} \mathrm{M}$ at neutral $\mathrm{pH}$, this binding complex is one of the strongest bonds known [38]. In fact, dried egg white $(1 \mathrm{~g})$ can bind approximately $11.5 \mu \mathrm{g}$ biotin [37]. Because a single molecule of avidin can bind four of biotin, the concentration of avidin added, either as pure protein or present in egg white, was in $50 \%$ excess in order to maximize vitamin removal. On average, grape musts from Washington contain approximately $2 \mu \mathrm{g} / \mathrm{L}$ biotin [41]. However, avidin can also react with phenolics present in wine [42], thereby rendering the protein inactive against biotin. To compensate, dialysis tubing with small enough porosity to prevent the migration of most phenolics (1000 MWCO) has been used [40].

Compared to the untreated controls, growth in treated wines significantly reduced $x_{\max }$ at both inoculum levels ( $10^{4}$ and $\left.10^{2} \mathrm{cfu} / \mathrm{mL}\right)$ and for both strains (2091 and I1a). The greater contrast was noted in wines inoculated with $10^{2} \mathrm{cfu} / \mathrm{mL}$, an important observation because low populations of this yeast can lead to spoilage [1]. Because these two strains represented two different genetic clusters and regions of isolation $[8,16]$, reductions in their populations suggests that avidin-based treatments may be effective against other strains. However, as some growth was still found to occur in treated wines, the use of avidin-based treatments should be considered as one of multiple hurdles necessary to limit spoilage. Although avidin has not been approved for use in winemaking, egg whites are readily used for clarifying commercial wines [1]. As biotin may be required by other microbial species beneficial to winemaking (e.g., alcoholic and malolactic fermentation), methods to remove biotin should be employed after completion of all fermentations. Future research should test for synergistic effects between avidin-based treatments and other hurdles known to help control B. bruxellensis.

Acknowledgments: The authors would like to thank the Northwest Center for Small Fruits Research (Corvallis, OR, USA) and the School of Food Science, Washington State University (Pullman, WA, USA) for their financial and material support. Strains of B. bruxellensis from the Phaff Collection were provided through the courtesy of C.M.L. Joseph (University of California, Davis, CA, USA).

Author Contributions: Nicolas H. von Cosmos and Charles G. Edwards conceived and designed the experiments, analyzed data, and wrote the manuscript; Nicolas $\mathrm{H}$. von Cosmos performed the experiments.

Conflicts of Interest: The authors declare no conflict of interest.

\section{Abbreviations}

$\begin{array}{ll}\text { MWCO } & \text { Molecular Weight Cut-Off } \\ \text { cfu } & \text { colony forming units }\end{array}$

\section{References}

1. Fugelsang, K.C.; Edwards, C.G. Wine Microbiology: Practical Applications and Procedures, 2nd ed.; Springer Science and Business Media: New York, NY, USA, 2007.

2. Chatonnet, P.; Duborudieu, D.; Boidron, J.N.; Pons, M. The origin of ethylphenols in wines. J. Sci. Food Agric. 1992, 60, 165-178. [CrossRef]

3. Fugelsang, K.C.; Zoecklein, B.W. Population dynamics and effects of Brettanomyces bruxellensis strains on Pinot noir (Vitis vinifera L.) wines. Am. J. Enol. Vitic. 2003, 54, 294-300.

4. Romano, A.; Perello, M.C.; Lonvaud-Funel, A.; Sicard, G.; de Revel, G. Sensory and analytical re-evaluation of "Brett character". Food Chem. 2009, 114, 15-19. [CrossRef]

5. Chatonnet, P.; Dubourdieu, D.; Boidron, J.N. The influence of Brettanomyces/Dekkera sp. yeasts and lactic acid bacteria on the ethylphenol content of red wines. Am. J. Enol. Vitic. 1995, 46, 463-468.

6. Barata, A.; Pagliara, D.; Piccininno, T.; Tarantino, F.; Ciardulli, W.; Malfeito-Ferreira, M.; Loureiro, V. The effect of sugar concentration and temperature on growth and volatile phenol production by Dekkera bruxellensis in wine. FEMS Yeast Res. 2008, 7, 1097-1102. [CrossRef] [PubMed]

7. Childs, B.C.; Bohlscheid, J.C.; Edwards, C.G. Impact of available nitrogen and sugar concentration in musts on alcoholic fermentation and subsequent wine spoilage by Brettanomyces bruxellensis. Food Microbiol. 2015, 46, 604-609. [CrossRef] [PubMed] 
8. Conterno, L.; Joseph, C.M.L.; Arvik, T.J.; Henick-Kling, T.; Bisson, L.F. Genetic and physiological characterization of Brettanomyces bruxellensis strains isolated from wines. Am. J. Enol. Vitic. 2006, 57, 139-147.

9. Burkholder, P.R.; McVeigh, I.; Moyer, D. Studies on some growth factors of yeasts. J. Bacteriol. 1944, 48, 385-391. [PubMed]

10. Van der Walt, J.P.; van Kerken, A.E. The wine yeasts of the Cape. Part II. The occurrence of Brettanomyces intermedius and Brettanomyces schanderlii in South African table wines. Antonie Leeuwenhoek 1959, 25, $145-151$. [CrossRef] [PubMed]

11. Wickerham, L.J. Taxonomy of Yeasts; United States Department of Agriculture: Washington, DC, USA, 1951.

12. Crauwels, S.; Zhu, B.; Steensels, J.; Busschaert, P.; Samblanx, G.D.; Marchal, K.; Willems, K.A.; Verstrepen, K.J.; Lievens, B. Assessing genetic diversity among Brettanomyces yeasts by DNA fingerprinting and whole-genome sequencing. Appl. Environ. Microbiol. 2014, 80, 4398-4413. [CrossRef] [PubMed]

13. Conterno, L.; Aprea, E.; Franceschi, P.; Viola, R.; Vrhovsek, U. Overview of Dekkera bruxellensis behaviour in an ethanol-rich environment using untargeted and targeted metabolomic approaches. Food Res. Int. 2013, 51, 670-678. [CrossRef]

14. Chandra, M.; Barata, A.; Ferreira-Dias, S.; Malfeito-Ferreira, M.; Loureiro, V. A response surface methodology study on the role of factors affecting growth and volatile phenol production by Brettanomyces bruxellensis ISA 2211 in wine. Food Microbiol. 2014, 42, 40-46. [CrossRef] [PubMed]

15. Barata, A.; Caldeira, J.; Boteheiro, R.; Pagliara, D.; Malfeito-Ferreira, M.; Loureiro, V. Survival patterns of Dekkera bruxellensis in wines and inhibitory effect of sulfur dioxide. Int. J. Food Microbiol. 2008, 121, 201-207. [CrossRef] [PubMed]

16. Jensen, S.L.; Umiker, N.L.; Arneborg, N.; Edwards, C.G. Identification and characterization of Dekkera bruxellensis, Candida pararugosa, and Pichia guilliermondii isolated from commercial red wines. Food Microbiol. 2009, 26, 915-921. [CrossRef] [PubMed]

17. Blomqvist, J.; Eberhard, T.; Schnürer, J.; Passoth, V. Fermentation characteristic of Dekkera bruxellensis strains. Appl. Microbiol. Biotechnol. 2010, 87, 1487-1497. [CrossRef] [PubMed]

18. Leistner, L. Basic aspects of food preservation by hurdle technology. Int. J. Food Microbiol. 2000, 55, 181-186. [CrossRef]

19. Zuehlke, J.M.; Edwards, C.G. Impact of sulfur dioxide and temperature on culturability and viability of Brettanomyces in wine. J. Food Prot. 2013, 76, 2024-2030. [CrossRef] [PubMed]

20. Umiker, N.L.; DeScenzo, R.; Lee, J.; Edwards, C.G. Removal of Brettanomyces bruxellensis from red wine using membrane filtration. J. Food Proc. Pres. 2013, 37, 799-805. [CrossRef]

21. Brandam, C.; Castro-Martine, C.; Delia, M.L.; Ramon-Portugal, F.; Strehaiano, P. Effect of temperature on Brettanomyces bruxellensis: Metabolic and kinetic aspects. Can. J. Microbiol. 2008, 54, 11-18. [CrossRef] [PubMed]

22. Guzzon, R.; Nardin, T.; Micheletti, O.; Nicolini, G.; Larcher, R. Antimicrobial activity of ozone. Effectiveness against the main wine spoilage microorganisms and evaluation of impact on simple phenols in wine. Aust. J. Grape Wine Res. 2013, 19, 180-188. [CrossRef]

23. Puertolas, E.; Lopez, N.; Condon, S.; Raso, J.; Alvarez, I. Pulsed electric fields inactivation of wine spoilage yeast and bacteria. Int. J. Food Microbiol. 2009, 130, 49-55. [CrossRef] [PubMed]

24. Lustrato, G.; Vigentini, I.; de Leonardis, A.; Alfano, G.; Tirelli, A.; Foschino, R.; Ranalli, G. Inactivation of wine spoilage yeast Dekkera bruxellensis using low electric current treatment. J. Appl. Microbiol. 2010, 109, 594-604. [PubMed]

25. Petrova, B.; Cartwright, Z.M.; Edwards, C.G. Effectiveness of chitosan preparations against Brettanomyces bruxellensis grown in culture media and red wines. J. Int. Sci. Vigne Vin 2016, 50, 49-57. [CrossRef]

26. Renouf, V.; Strehaiano, P.; Lonvaud-Funel, A. Effectiveness of dimethyldicarbonate to prevent Brettanomyces bruxellensis growth in wine. Food Cont. 2008, 19, 208-216. [CrossRef]

27. Zuehlke, J.M.; Glawe, D.A.; Edwards, C.G. Efficacy of dimethyl dicarbonate against yeasts associated with Washington State grapes and wines. J. Food Proc. Pres. 2015, 39, 1016-1026. [CrossRef]

28. Zuehlke, J.M.; Petrova, B.; Edwards, C.G. Advances in the control of wine spoilage by Zygosaccharomyces and Dekkera/Brettanomyces. Ann. Rev. Food Sci. Technol. 2013, 4, 57-78. [CrossRef] [PubMed]

29. Sturm, M.E.; Arroyo-López, F.N.; Garrido-Fernández, A.; Querol, A.; Mercado, L.A.; Ramirez, M.L.; Combina, M. Probabilistic model for the spoilage wine yeast Dekkera bruxellensis as a function of $\mathrm{pH}$, ethanol and free $\mathrm{SO}_{2}$ using time as a dummy variable. Int. J. Food Microbiol. 2014, 170, 83-90. [CrossRef] [PubMed] 
30. Kurtzman, C.P.; Fell, J.W.; Boekhout, T. The Yeasts: A Taxonomic Study, 5th ed.; Elsevier: Amsterdam, NY, USA, 2011; pp. 53-986.

31. Buechsenstein, J.; Ough, C.S. $\mathrm{SO}_{2}$ determination by aeration-oxidation: A comparison with Ripper. Am. J. Enol. Vitic. 1978, 29, 161-164.

32. Angyal, G. Biotin. In US Food and Drug Administration. Methods for the Microbiological Analysis of Selected Nutrients; Association of Official Analytical Chemists: Arlington, VA, USA, 1996; pp. 9-10.

33. Madan, M.; Gulati, N. Organic growth factor requirements of some yeasts. Microbios 1980, 28, 167-172. [PubMed]

34. Aguilar-Uscanga, M.G.; Delia, M.L.; Strehaiano, P. Nutritional requirements of Brettanomyces bruxellensis: Growth and physiology in batch and chemostat cultures. Can. J. Microbiol. 2000, 46, 1046-1050. [CrossRef] [PubMed]

35. Jones, R.P.; Greenfield, P.F. Ethanol and the fluidity of the yeast plasma membrane. Yeast 1987, 3, $223-232$. [CrossRef] [PubMed]

36. Rose, A.H.; Harrison, J.S. The Yeasts, 5th ed.; Academic Press: London, UK, 1971; Volume 2, pp. 3-60.

37. Hertz, R.; Sebrell, W.H. Occurrence of avidin in the oviduct and secretions of the genital tract of several species. Science 1942, 96. [CrossRef] [PubMed]

38. Korpela, J. Avidin, a high affinity biotin-binding protein, as a tool and subject of biological research. Med. Biol. 1984, 62, 5-26. [PubMed]

39. Bohlscheid, J.C.; Fellman, J.K.; Wang, X.D.; Ansen, D.; Edwards, C.G. The influence of nitrogen and biotin interactions on the performance of Saccharomyces in alcoholic fermentations. J. Appl. Microbiol. 2007, 102, 390-400. [CrossRef] [PubMed]

40. Zarogiannis, S.; Liakopoulos, V.; Hatzoglou, C.; Vogiatzidis, K.; Salmas, M.; Stefanidis, I.; Gourgoulianis, K.; Molyvdas, P.A.; Lafis, S. Development of an egg-white bioassay for monitoring biotin levels in urine and serum. Anal. Sci. 2007, 23, 593-595. [CrossRef] [PubMed]

41. Hagen, K.M.; Keller, M.; Edwards, C.G. Survey of biotin, pantothenic acid, and assimilable nitrogen in winegrapes from the Pacific Northwest. Am. J. Enol. Vitic. 2008, 59, 432-436.

42. Haider, K.; Frederick, L.R.; Flaig, W. Reactions between amino acid compounds and phenols during oxidation. Plant Soil. 1965, 22, 49-64. [CrossRef]

(C) 2016 by the authors; licensee MDPI, Basel, Switzerland. This article is an open access article distributed under the terms and conditions of the Creative Commons Attribution (CC-BY) license (http:/ / creativecommons.org/licenses/by/4.0/). 